\author{
Marcin Salamaga \\ Katedra Statystyki \\ Uniwersytet Ekonomiczny w Krakowie
}

\title{
Identyfikacja determinantów wyboru destynacji polskich inwestycji bezpośrednich poza obszarem Unii Europejskiej
}

\section{Streszczenie}

Celem artykułu jest identyfikacja i hierarchizacja czynników decydujących o wyborze destynacji polskich bezpośrednich inwestycji zagranicznych poza obszarem Unii Europejskiej. Przedmiotem badania są czynniki o charakterze kosztowym, rynkowym, efektywnościowym, prawnym, społecznym i politycznym, które mogą mieć znaczenie dla poszukiwania beneficjentów BIZ. W artykule posłużono się danymi pochodzącymi z badania ankietowego przeprowadzonego wśród polskich przedsiębiorstw podejmujących BIZ lub planujących tę formę inwestowania. Do klasyfikacji firm zastosowano drzewa decyzyjne tworzone zgodnie z procedurą CART. Metoda ta umożliwiła stworzenie profili przedsiębiorstw o zbliżonej polityce inwestycyjnej w zakresie priorytetów wyboru destynacji BIZ. W badaniu wykazano, że najważniejsze przy wyborze destynacji BIZ na terenie pozaunijnych państw europejskich okazywały się czynniki prawne i kosztowe, a w przypadku destynacji pozaeuropejskich ważne były także czynniki polityczne. Priorytetowe traktowanie czynników prawnych może oznaczać, że część polskich firm jest zainteresowana inwestycjami BIZ w postaci przepływów finansowych (tzw. kapitał w tranzycie) i stosuje optymalizację podatkową.

Słowa kluczowe: BIZ, badanie ankietowe, drzewa klasyfikacyjne, algorytm CART. 


\section{Wprowadzenie}

Przepływy bezpośrednich inwestycji zagranicznych (BIZ) odgrywają ważną rolę w rozwoju gospodarczym wielu krajów. Ich rozmiary stanowią wypadkową stopnia otwartości poszczególnych gospodarek. Eksporterami BIZ są kraje wysoko rozwinięte, o znacznym potencjale gospodarczym i z odpowiednio wysoką akumulacją kapitału. Do niedawna Polska była postrzegana głównie jako importer BIZ. Jednak od kilku lat to polskie firmy coraz częściej poszukują możliwości inwestowania na rynkach zagranicznych, a forma BIZ zajmuje wśród nich ważne miejsce. $Z$ dotychczasowych danych wynika, że głównymi odbiorcami polskich BIZ są kraje Unii Europejskiej. W 2013 r. wartość zasobów polskich BIZ zlokalizowanych na terenie UE stanowiła ponad 70\% całkowitej wartości BIZ eksportowanych z Polski (http://www.nbp.pl/, dostęp: 20.08.2015). Tę pozycję kraje UE zawdzięczają m.in. wewnątrzunijnym regulacjom prawnym gwarantującym swobodny przepływ osób, towarów, usług i kapitału. Niemniej jednak wiele polskich firm szuka możliwości lokowania BIZ poza obszarem UE. Ta destynacja inwestycji bezpośrednich może być atrakcyjna m.in. z powodu niskich kosztów pracy, surowców czy nowych rynków zbytu, jak i innych uwarunkowań charakterystycznych dla poszczególnych krajów - beneficjentów BIZ.

Motywy bezpośrednich inwestycji zagranicznych są obszernie opisywane w krajowej i zagranicznej literaturze przedmiotu [Dunning 2004, Fry 1993, Jun, Singh 1996, Mottaleb 2007, Przybylska 2001, Witkowska 1996, Wawrzyniak 2010]. Wśród licznych determinantów BIZ często powtarzają się czynniki o charakterze kosztowym, rynkowym, handlowym oraz czynniki tworzące klimat inwestycyjny [Lukas 1993, Pilarska 2005, Rymarczyk 2004]. Czynniki lokalizacyjne, czyli decydujące o korzystniejszych warunkach produkcji w kraju goszczącym BIZ w porównaniu z krajem macierzystym, są szeroko analizowane w tzw. teorii czynników lokalizacyjnych. W ramach tej teorii ekonomiści próbują wyjaśnić strukturę lokowania BIZ, zakładając, że firmy dysponują przewagami konkurencyjnymi. Jest to jedna z wielu teorii wyjaśniających mechanizm BIZ. Napływ inwestycji bezpośrednich w powiązaniu z innymi wielkościami makroekonomicznymi jest też tłumaczony w teoriach rozwoju gospodarczego [Dunning 1981a], korzyści komparatywnych [Kojima 1978], dynamicznych przewag komparatywnych [Ozawa 1992], eklektycznej teorii produkcji międzynarodowej [Dunning 1981b, 1988] i innych.

W niniejszym artykule teoria czynników lokalizacyjnych stanowiła inspirację do przeprowadzenia badania empirycznego wśród polskich przedsiębiorców, którego celem jest wskazanie kluczowych czynników wyboru lokalizacji BIZ. $\mathrm{W}$ artykule skupiono się na destynacjach BIZ zlokalizowanych poza UE. Wprawdzie obecnie tylko około 1/3 polskich BIZ jest lokowana w tym obszarze, jednak 
udział pozaunijnych beneficjentów BIZ w całkowitej strukturze polskich inwestycji bezpośrednich wykazuje tendencję wzrostową (http://www.nbp.pl/, dostęp: 20.08.2015) i ten rynek inwestycyjny wydaje się perspektywiczny dla wielu polskich firm.

Analizę wykonano na podstawie danych pozyskanych z badania ankietowego przeprowadzonego wśród polskich firm inwestujących lub planujących inwestycje bezpośrednie za granicą. Do wykrycia zależności pomiędzy motywacjami podjęcia BIZ i wyborami ich destynacji zastosowano drzewa klasyfikacyjne CART. Metoda ta posłużyła również do segmentacji eksporterów BIZ, którzy kierują się podobnymi motywami, poszukując dogodnej lokalizacji dla inwestycji bezpośrednich. Dotychczas w opracowaniach naukowych poświęconych badaniu zależności pomiędzy motywacjami i destynacjami BIZ unika się stosowania wielowymiarowych metod statystycznych, chociaż ułatwiają one wykrycie faktycznych powiązań pomiędzy zmiennymi i wzmacniają siłę formułowanych wniosków. Zaproponowane postępowanie badawcze wykorzystujące analizę CART należy uznać za oryginalne w kontekście celu pracy. Wyniki przedstawione w artykule stanowią również przegląd aktualnych preferencji polskich przedsiębiorstw w zakresie pozaunijnych destynacji BIZ w powiązaniu z motywami wyboru tych destynacji.

\section{Metoda badawcza}

Identyfikację czynników determinujących wybór destynacji polskich BIZ przeprowadzono wykorzystując drzewa klasyfikacyjne CART (Classification and Regression Trees) [Breiman i in. 1984]. Algorytm CART pozwala na generowanie drzew decyzyjnych, czyli grafów o strukturze drzewiastej. Składają się one z węzła początkowego (korzenia), węzłów podlegających podziałowi na węzły potomne oraz węzłów końcowych (liści). Jeżeli zmienna zależna jest mierzona na skali nominalnej lub porządkowej, to mówimy o drzewach klasyfikacyjnych, jeśli natomiast zmienna zależna jest mierzona na skali co najmniej przedziałowej, to mamy do czynienia $\mathrm{z}$ drzewami regresyjnymi.

Drzewa decyzyjne pozwalają na podział wielowymiarowej przestrzeni zmiennych na $K$ rozłączne podzbiory zgodnie z funkcją klasyfikacyjną [Gatnar 2009]:

gdzie:

$$
f\left(x_{i}\right)=\sum_{k=1}^{K} \alpha_{k} I\left(x_{i}\right),
$$

$\alpha_{k}$ - parametry modelu,

$I\left(x_{i}\right)$ - funkcja wskaźnikowa postaci: 


$$
I\left(x_{i}\right)=\left\{\begin{array}{lll}
1, & \text { gdy } & x_{i} \in R_{k} \\
0, & \text { gdy } & x_{i} \notin R_{k}
\end{array}\right.
$$

gdzie:

$R_{k}(k=1,2, \ldots, K)$ - podprzestrzenie przestrzeni $X^{m}$.

Sposób szacowania parametrów $\alpha_{k}$ zależy od skali, na jakiej mierzona jest zmienna zależna $Y$. Jeśli zmienna $Y$ jest mierzona na skali nominalnej, to:

$$
\alpha_{k}=\underset{t}{\arg \max } p\left(P_{t} \mid x_{i} \in R_{k}\right),
$$

gdzie: $P_{t}(t=1,2, \ldots, u)$ - klasa, do której należy obserwacja $x_{i}$.

W przypadku gdy zmienna Y jest mierzona na skali co najmniej przedziałowej, to parametr $\alpha_{k}$ jest średnią wartością zmiennej Y dla obserwacji znajdujących się w podprzestrzeni $R_{k}$.

Aby ocenić jakość podziału przestrzeni $R$ na rozłączne segmenty $R_{l}, R_{2}, \ldots, R_{k}$, można wykorzystać formułę [Gatnar 2009]:

gdzie:

$$
\Delta Q(R)=Q(R)-\sum_{s=1}^{K} Q\left(R_{k}\right) p_{k},
$$

$Q\left(R_{k}\right)$ - funkcja zróżnicowania obserwacji znajdujących się w podprzestrzeni $R_{k}$,

$p_{k}$ - frakcja obserwacji w podprzestrzeni $R_{k}$.

Najwyższą jednorodność wydzielanych podprzestrzeni można osiągnąć poprzez maksymalizację wyrażenia (3). Postać funkcji $Q\left(R_{k}\right)$ zależy od rodzaju tworzonego drzewa decyzyjnego. W przypadku drzew klasyfikacyjnych, oceniając homogeniczność podprzestrzeni $R_{k}$, stosuje się przeważnie błąd klasyfikacji, wskaźnik Giniego lub miarę entropii. Jeśli zmienna $X$ jest mierzona na słabej skali, to zbiór jej kategorii jest dzielony na takie dwa podzbiory, aby wartość wyrażenia (3) była możliwie największa.

W konstrukcji drzew dyskryminacyjnych niepożądanym zjawiskiem jest nadmierna złożoność modelu powiązana ze wzrostem wartości błędu dla zbioru testowego. W praktyce ogranicza się to zjawisko za pomocą przycinania krawędzi drzewa (pruning). Jest to proces sekwencyjny, który prowadzi do eliminowania tych gałęzi drzewa, których brak nie skutkuje nadmiernym pogorszeniem jakości podziałów. W efekcie uzyskuje się zbiór drzew, z których wybierane jest to, dla którego błąd klasyfikacji dotyczący zbioru testowego jest minimalny [Gatnar 2001].

Interpretując drzewa dyskryminacyjne CART, stosuje się reguły klasyfikacyjne formułowane dla ścieżki drzewa łączącej korzeń z określonym liściem. Jednym z powodów wyboru analizy CART do klasyfikacji eksporterów BIZ jest jej efektywność w predykcji jakościowej, gdy stosowalność wielu innych metod ilościowych jest ograniczona. Zaletami analizy CART są również jej odporność na 
występowanie jednostek nietypowych, brak wymagań co do liniowości związków pomiędzy zmiennymi, jak również dopuszczalność wykorzystania zmiennych charakteryzujących się brakami danych [Gatnar 2001].

\section{Charakterystyka próby badawczej}

Źródłem danych wykorzystanych w procedurze CART było badanie ankietowe przeprowadzone w okresie od grudnia 2014 r. do kwietnia 2015 r. wśród polskich firm, które lokowały bezpośrednie inwestycje za granicą lub też dysponowały potencjałem umożliwiającym taką formę inwestowania ${ }^{1}$. Kwestionariusz anonimowej ankiety rozesłano do około 800 przedsiębiorstw działających w różnych branżach gospodarki. Zwrot ankiet był na poziomie prawie $60 \%$, a po ostatecznej selekcji nadesłanych odpowiedzi w badaniu uwzględniono 436 poprawnie wypełnione kwestionariusze. Na rys. 1 przedstawiono przestrzenną strukturę ankietowanych przedsiębiorstw eksportujących BIZ. Najwięcej badanych firm pochodziło z województw mazowieckiego (59 firmy) i śląskiego (38 firmy), a najmniej z województwa warmińsko-mazurskiego (11 firm).

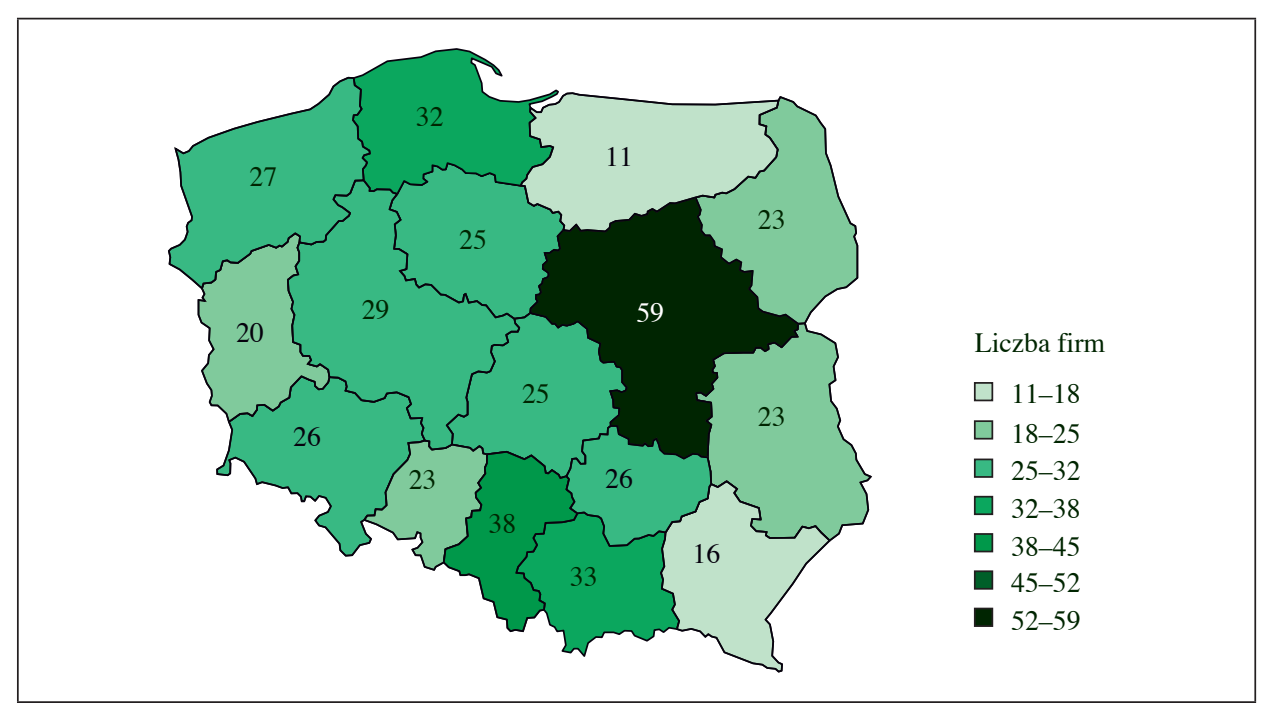

Rys. 1. Struktura przestrzenna ankietowanych przedsiębiorstw

Źródło: opracowanie własne na podstawie wyników badania ankietowego przeprowadzonego od grudnia 2014 r. do kwietnia 2015 r.

${ }^{1}$ Informacje na temat ankietowanych przedsiębiorstw pozyskano z ogólnodostępnych elektronicznych baz firm, w tym firm zrzeszonych w Polskiej Konfederacji Pracodawców Prywatnych Lewiatan oraz odnotowanych przez Polską Izbę Inwestycji Zagranicznych. 
Na rys. 2 przedstawiono branżową strukturę ankietowanych firm (według sekcji PKD) prowadzących BIZ lub planujących uruchomić tę formę inwestycji.

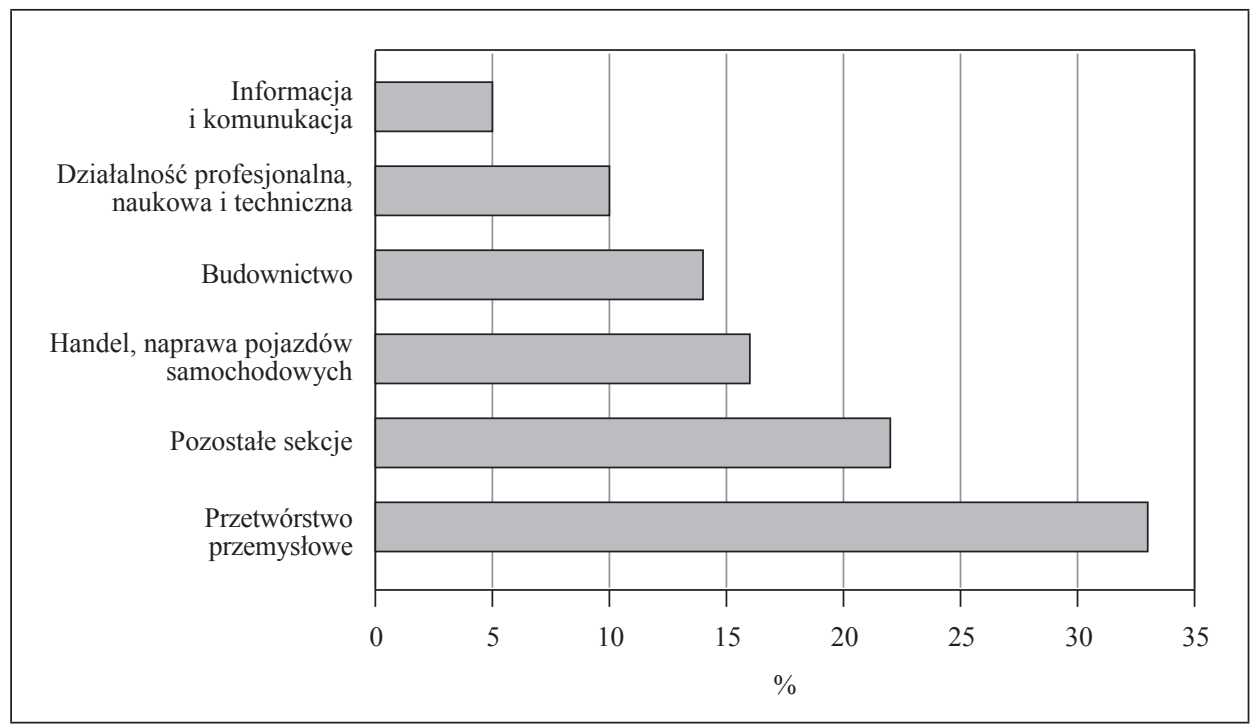

Rys. 2. Struktura branżowa ankietowanych firm

Źródło: opracowanie własne na podstawie wyników badania ankietowego przeprowadzonego od grudnia 2014 r. do kwietnia 2015 r.

Wśród badanych firm najwięcej było przedsiębiorstw reprezentujących branże przetwórstwa przemysłowego (33\%), pozostałe sekcje PKD (22\%) oraz handel i naprawę pojazdów samochodowych (16\%). Ankietowane przedsiębiorstwa były również badane pod względem wartości bezpośrednich inwestycji, które lokują lub planują ulokować za granicą. Z badania wynika, że najwięcej (38\%) firm inwestuje lub jest skłonna zainwestować w formie BIZ kwotę od 5 do 10 mln EUR, a 34\% przeznacza powyżej $10 \mathrm{mln}$ EUR na tego typu inwestycje. Najmniejszą grupę stanowiły firmy (10\%), których wartość BIZ wynosi mniej niż 1 mln EUR.

Spośród różnych czynników, o jakie pytano respondentów, zdecydowano się ostatecznie na uwzględnienie w niniejszej analizie sześciu grup czynników: kosztowych, rynkowych, efektywnościowych, prawnych, społecznych i politycznych.

Takie wieloaspektowe podejście do motywów wyboru kraju - beneficjenta BIZ wydaje się uzasadnione zwłaszcza wobec niestabilnej sytuacji gospodarczej i politycznej na świecie w ostatnich latach. Długoterminowa forma lokowania kapitału, jaką stanowią BIZ powoduje, że ewentualne przyszłe zawirowania społeczno-polityczne w kraju przeznaczenia BIZ mogą powodować znaczne straty firmy inwestującej. Stąd decyzja o wyborze kraju goszczącego BIZ musi być dobrze przemy- 
ślana nie tylko pod względem ekonomicznym. Zatem inwestor oprócz kryteriów ekonomicznych musi brać pod uwagę również inne czynniki, których znajomość pozwoli na zminimalizowanie ryzyka całego przedsięwzięcia. W ramach każdej z wyróżnionych grup determinantów ankietowany inwestor miał do wyboru jeden z dwóch czynników który - jego zdaniem - w większym stopniu wpłynie na decyzję o wyborze kierunku BIZ. Tabela 1 zawiera bezwzględne liczby wskazań oraz odsetki wskazań poszczególnych determinantów wyboru destynacji BIZ.

Wśród determinantów kosztowych respondenci najczęściej wskazywali na poziom kosztów pracy w kraju goszczącym BIZ jako na wiodący czynnik wyboru kierunku eksportu BIZ. Wśród determinantów rynkowych takim wiodącym czynnikiem są nowe rynki zbytu, a wśród czynników efektywnościowych - modernizacja metod produkcji, wśród czynników prawnych - prawodawstwo gospodarcze i administracyjne, wśród czynników społecznych - kwalifikacje kadry pracowniczej w kraju przyjmującym BIZ, natomiast wśród czynników politycznych stabilność polityczna w kraju goszczącym przyjmującym BIZ.

Tabela 1. Grupy determinantów wyboru destynacji BIZ

\begin{tabular}{|l|l|c|c|}
\hline \multirow{2}{*}{ Grupa czynników } & \multicolumn{2}{|c|}{ Kategoria } & \multicolumn{2}{|c|}{ Odpowiedzi } \\
\cline { 3 - 4 } & & liczba & procent \\
\hline \multirow{2}{*}{ Kosztowe } & koszty pracy & 236 & 54,13 \\
\cline { 2 - 4 } & ceny zasobów naturalnych & 200 & 45,87 \\
\hline \multirow{2}{*}{ Rynkowe } & nowe rynki zbytu & 254 & 58,26 \\
\cline { 2 - 4 } & poszukiwanie niszy rynkowej & 182 & 41,74 \\
\hline \multirow{2}{*}{ Prawnektywnościowe } & kooperacja z lokalnymi firmami & 205 & 47,02 \\
\cline { 2 - 4 } & modernizacja metod produkcji & 231 & 52,98 \\
\hline \multirow{2}{*}{ Społeczne } & polityka celna i podatkowa & 148 & 33,94 \\
\cline { 2 - 4 } & prawodawstwo gospodarcze & 288 & 66,06 \\
\hline Polityczne & i administracyjne & & 62,84 \\
\cline { 2 - 4 } & kwalifikacje kadry pracowniczej & 274 & 37,16 \\
\cline { 2 - 4 } & poziom zamożności społeczeństwa & 162 & 30,96 \\
\cline { 2 - 4 } & stopień ingerencji państwa & 135 & 69,04 \\
\cline { 2 - 4 } & w gospodarkę & 301 & \\
\hline
\end{tabular}

Źródło: opracowanie własne na podstawie wyników badania ankietowego przeprowadzonego od grudnia 2014 r. do kwietnia 2015 r.

Można się spodziewać, że niektóre połączenia czynników wymienionych w tabeli 1 mogą determinować wybór konkretnych kierunków eksportu BIZ. Jest to przedmiotem analizy w następnym punkcie artykułu. 


\section{Wyniki segmentacji firm eksportujących BIZ}

Chociaż głównym odbiorcą polskich BIZ są kraje UE, to jednak coraz więcej firm poszukuje możliwości inwestowania poza wspólnym rynkiem europejskim. Pozaunijnymi odbiorcami polskich BIZ są kraje europejskie nienależące do UE, kraje azjatyckie, kraje obu Ameryk i innych kontynentów. Najważniejszą deklarowaną destynację dla polskich BIZ poza UE stanowią kraje europejskie nienależące do UE, dlatego analizę determinantów wyboru kierunku BIZ postanowiono przeprowadzić osobno dla tych państw, a następnie dla krajów znajdujących się na innych kontynentach.

W pierwszej kolejności respondentom przedstawiono do wyboru kraje europejskie położone poza wspólnym rynkiem UE, które w ostatnich latach były ważnymi odbiorcami polskich BIZ (http://www.nbp.pl/, dostęp: 20.08.2015). Wzięto tutaj pod uwagę Szwajcarię, Rosję, Norwegię i inne kraje.

Wyniki odpowiedniej analizy CART ze względu na zmienną zależną ,perspektywiczny europejski beneficjent BIZ spoza UE” przedstawiono na rys. 3.

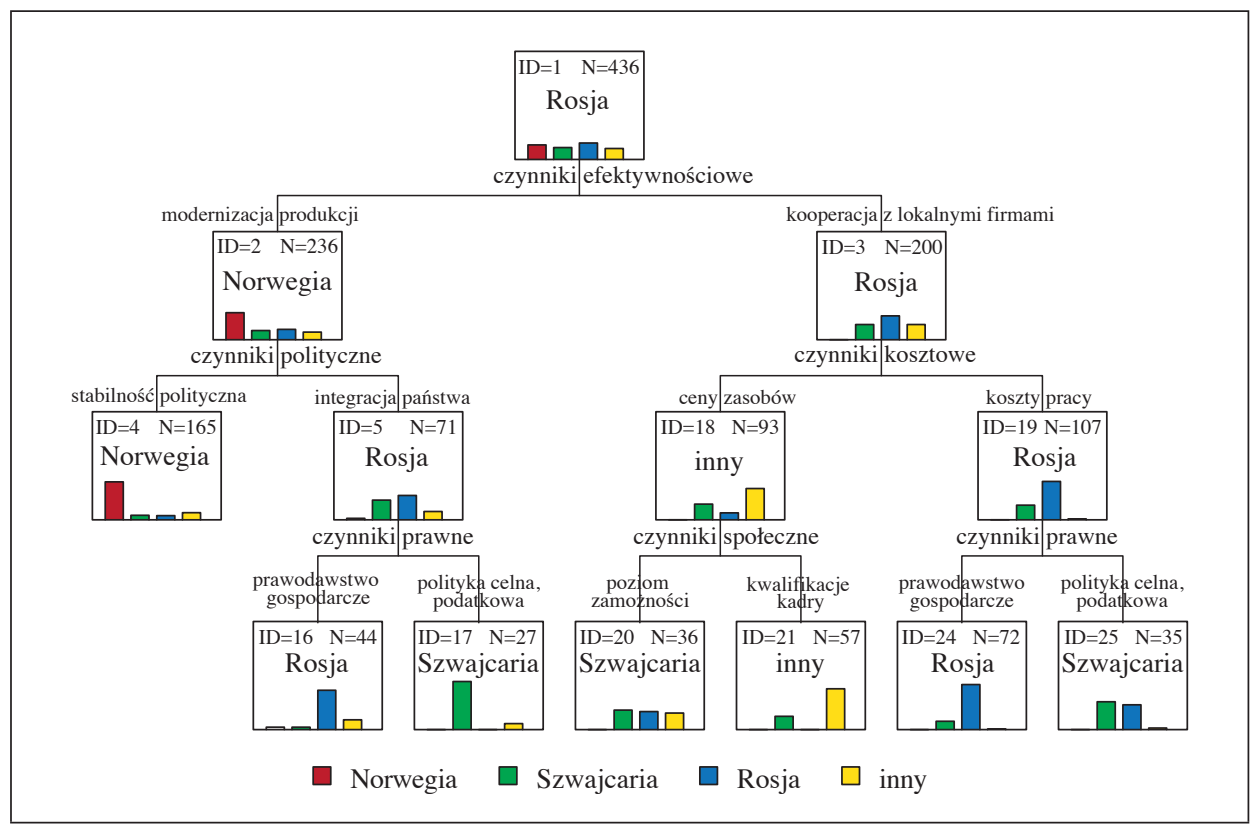

Rys. 3. Drzewo klasyfikacyjne CART dla zmiennej zależnej „,perspektywiczny europejski beneficjent BIZ spoza UE"

Źródło: opracowanie własne na podstawie wyników badania ankietowego przeprowadzonego od grudnia 2014 r. do kwietnia 2015 r. 
Przedmiotowe drzewo ma 7 węzłów końcowych i 6 węzłów dzielonych. Utworzone w wyniku podziału metodą CART homogeniczne podzbiory mogą być traktowane jako segmenty dostawców BIZ, którzy preferują te same kierunki eksportu BIZ przy określonych kombinacjach kategorii cech reprezentujących czynniki kosztowe, rynkowe, efektywnościowe, prawne, społeczne i polityczne. Interpretację wyników analizy CART przeprowadzono dla wybranych segmentów eksporterów BIZ wyznaczonych przez węzły końcowe drzewa klasyfikacyjnego.

Analizując kolejne poziomy drzewa CART, począwszy od korzenia po liście końcowe, można sformułować następujące przykładowe reguły:

- jeżeli dostawca BIZ, wybierając rynek inwestycyjny, za priorytetowe uważa modernizację metod produkcji i stabilność polityczną w kraju goszczącym BIZ (węzeł nr 4), to najprawdopodobniej wybierze Norwegię (z prawdopodobieństwem około 0,70 ),

- jeżeli eksporter BIZ za wiodące w poszukiwaniu rynku inwestycyjnego uzna kryteria: modernizację metod produkcji, poziom ingerencji państwa - beneficjanta BIZ w gospodarkę oraz prawodawstwo gospodarcze i administracyjne w kraju goszczącym BIZ (węzeł nr 16), to z prawdopodobieństwem około 0,73 wybierze rynek rosyjski,

- jeżeli firma, poszukując odbiorcy BIZ, za istotne uważa kooperację z miejscowymi firmami, ceny zasobów naturalnych oraz kwalifikacje kadry pracowniczej (węzeł nr 21), to najprawdopodobniej wybierze inny kraj niż Norwegia, Szwajcaria czy Rosja (z prawdopodobieństwem około 0,75),

- jeżeli dostawca BIZ, wybierając rynek inwestycyjny, za priorytetowe uważa kooperację z miejscowymi firmami, ceny zasobów naturalnych oraz politykę celną i podatkową w kraju goszczącym BIZ (węzeł nr 25), to najprawdopodobniej wybierze Szwajcarię (z prawdopodobieństwem około 0,51).

Na rys. 4 przedstawiono wyniki trafności klasyfikacji eksporterów BIZ przeprowadzonej za pomocą metody CART.

Najwięcej trafnie zakwalifikowanych eksporterów BIZ w aktualnej analizie CART znalazło się wśród tych, którzy za najbardziej perspektywiczny dla swoich inwestycji bezpośrednich uważają rynek norweski (około 89\% eksporterów BIZ), a w dalszej kolejności - Rosję (około 69\%). Na podstawie badania siły poszczególnych predyktorów w różnicowaniu segmentów eksporterów BIZ $\mathrm{w}$ ramach przedmiotowej analizy CART stwierdzono, że największy wpływ na wybór perspektywicznego europejskiego odbiorcy BIZ spoza UE miały czynniki prawne, kosztowe, a najmniej istotne okazały się czynniki efektywnościowe i społeczne. Szczegółowe wyniki rankingu ważności czynników w analizie CART przedstawiono na rys. 5.

W kolejnym etapie badań analizowano wybory respondentów odnoszące się do pozaeuropejskich krajów, które w ostatnich latach były ważnymi odbiorcami polskich BIZ. Uwzględniono duże gospodarki światowe, takie jak: USA, Chiny, Indie i inne kraje. 


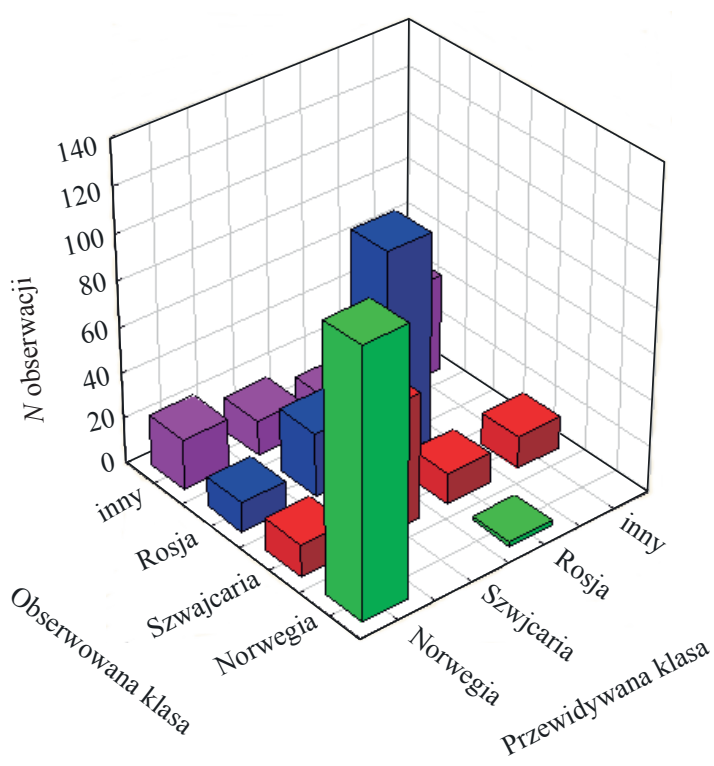

Rys. 4. Wyniki trafności klasyfikacji eksporterów BIZ przeprowadzonej za pomocą drzewa CART dla zmiennej zależnej ,perspektywiczny europejski beneficjent BIZ spoza UE”

Źródło: opracowanie własne na podstawie wyników badania ankietowego przeprowadzonego od grudnia 2014 r. do kwietnia 2015 r.

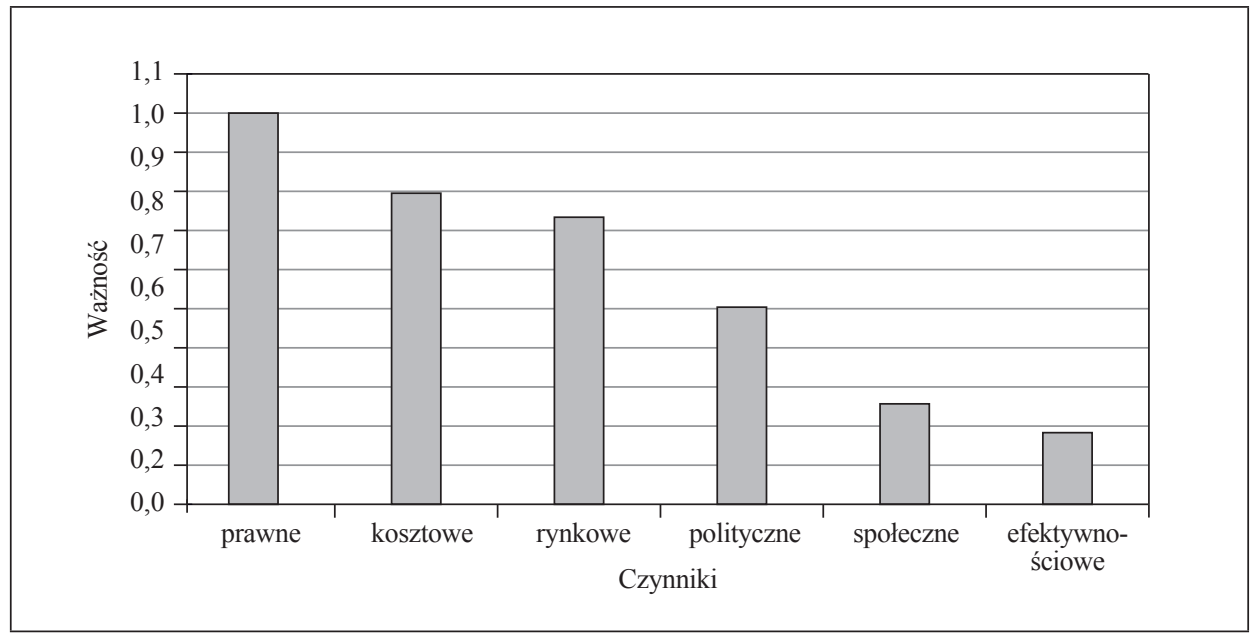

Rys. 5. Ranking ważności predyktorów w analizie CART dla zmiennej zależnej „perspektywiczny europejski beneficjent BIZ spoza UE”

Źródło: opracowanie własne na podstawie wyników badania ankietowego przeprowadzonego od grudnia 2014 r. do kwietnia 2015 r. 
Wyniki analizy CART przeprowadzonej ze względu na zmienną zależną „perspektywiczny pozaeuropejski beneficjent BIZ” przedstawiono na rys. 6 .

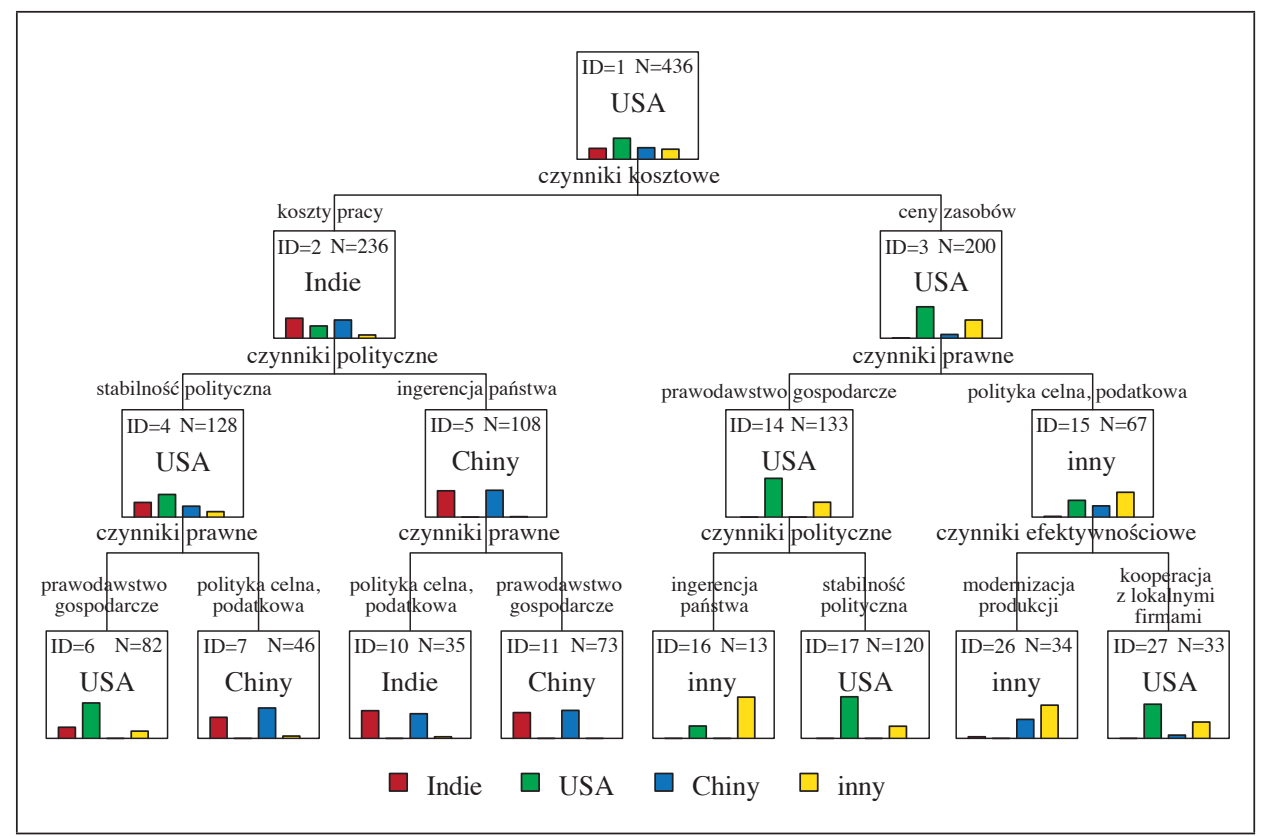

Rys. 6. Drzewo klasyfikacyjne CART dla zmiennej zależnej „perspektywiczny beneficjent BIZ spoza Europy"

Źródło: opracowanie własne na podstawie wyników badania ankietowego przeprowadzonego od grudnia 2014 r. do kwietnia 2015 r.

Prezentowane drzewo ma 8 węzłów końcowych i 7 węzłów dzielonych. Analizując układ tego drzewa, można sformułować następujące (wybrane) reguły decyzyjne:

- jeżeli eksporter BIZ za wiodące w poszukiwaniu rynku inwestycyjnego uzna kryteria: koszty pracy, stabilność polityczną oraz prawodawstwo gospodarcze i administracyjne w kraju goszczącym BIZ (węzeł nr 6), to z prawdopodobieństwem około 0,66 wybierze USA,

- jeżeli eksporter BIZ kieruje się kosztami pracy, stopniem ingerencji państwa w gospodarkę oraz prawodawstwem gospodarczym i administracyjnym w kraju goszczącym BIZ (węzeł nr 11), to z prawdopodobieństwem około 0,48 wybierze Chiny,

- jeżeli firma eksportująca BIZ za priorytetowe uważa koszty pracy, ingerencję państwa w gospodarkę oraz politykę celną i podatkową w kraju goszczącym BIZ 


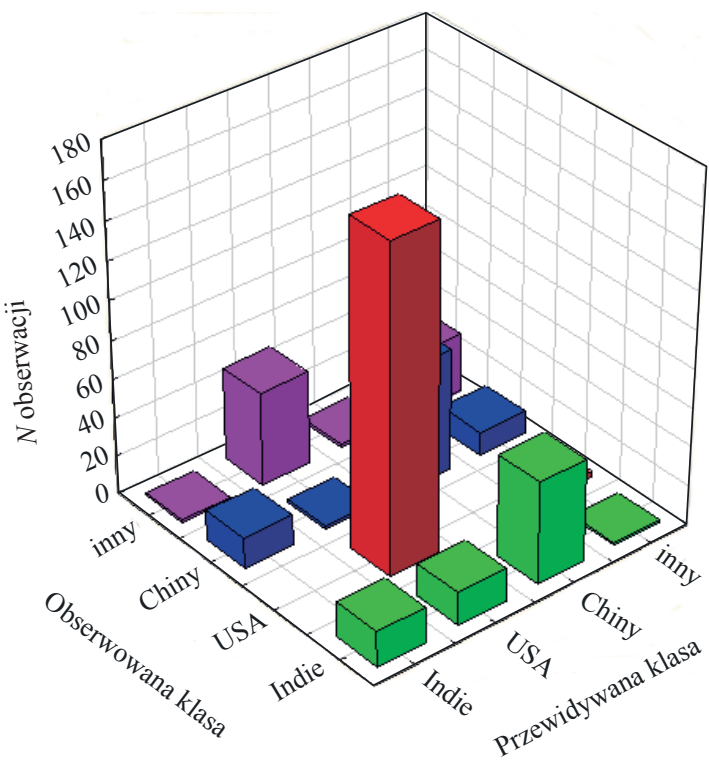

Rys. 7. Wyniki trafności klasyfikacji eksporterów BIZ przeprowadzonej za pomocą drzewa CART dla zmiennej zależnej ,,perspektywiczny beneficjent BIZ spoza Europy” Źródło: opracowanie własne na podstawie wyników badania ankietowego przeprowadzonego od grudnia 2014 r. do kwietnia 2015 r.

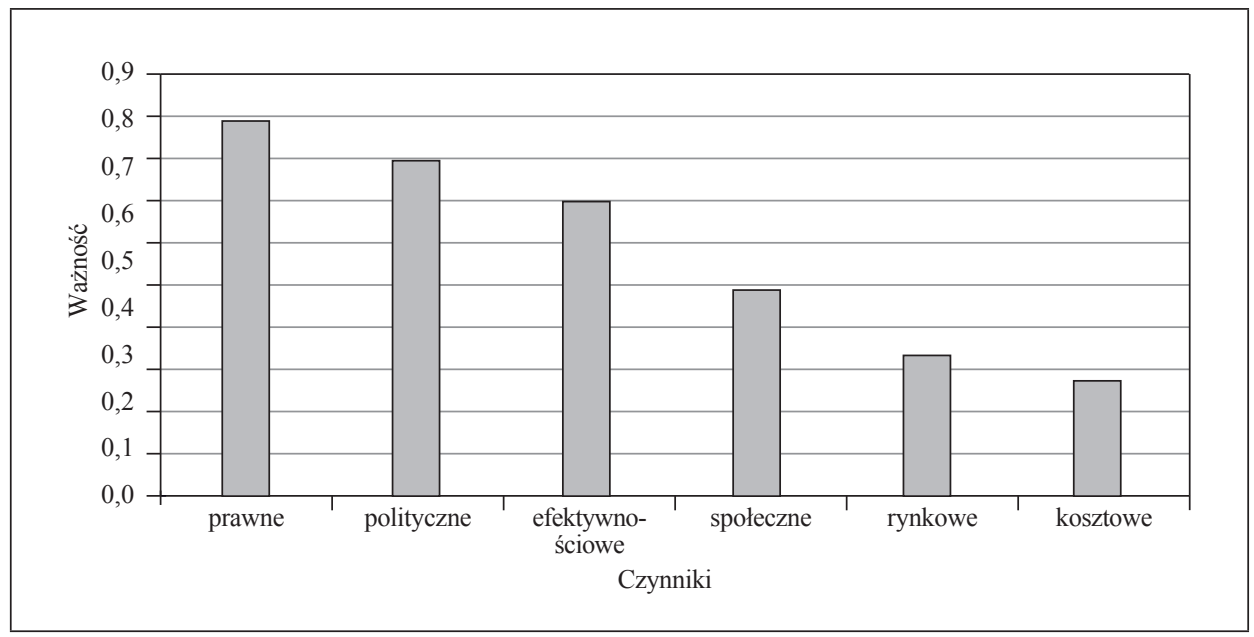

Rys. 8. Ranking ważności predyktorów w analizie CART dla zmiennej zależnej „perspektywiczny beneficjent BIZ spoza Europy”

Źródło: opracowanie własne na podstawie wyników badania ankietowego przeprowadzonego od grudnia 2014 r. do kwietnia 2015 r. 
(węzeł nr 10), to najprawdopodobniej wybierze Indie (z prawdopodobieństwem około 0,51 ),

- jeżeli eksporter BIZ za najbardziej istotne w poszukiwaniu rynku inwestycyjnego uzna kryteria: ceny zasobów naturalnych, prawodawstwo gospodarcze i administracyjne oraz stabilność polityczną w kraju przyjmującym BIZ (węzeł $\mathrm{nr}$ 17), to z prawdopodobieństwem około 0,78 wybierze USA,

- jeżeli dostawca BIZ kieruje się cenami zasobów naturalnych, polityką celną i podatkową oraz modernizacją metod produkcji (węzeł nr 26), to z prawdopodobieństwem około 0,62 wybierze inny kraj niż USA, Chiny i Indie.

Najwięcej trafnie zakwalifikowanych firm w powyższej analizie CART znalazło się wśród takich, które za najbardziej perspektywiczny dla swoich bezpośrednich inwestycji zagranicznych uważają USA (około 86\% eksporterów BIZ), a w dalszej kolejności - Chiny (około 65\% firm), rys. 7.

Na podstawie badania siły poszczególnych predyktorów w różnicowaniu segmentów eksporterów BIZ w ramach przedmiotowej analizy CART stwierdzono, że największy wpływ na wybór perspektywicznego odbiorcy BIZ spoza Europy miały czynniki prawne i polityczne, a najmniej istotne okazały się czynniki kosztowe i rynkowe (rys. 8).

\section{Podsumowanie}

UE jest ważnym kierunkiem eksportu polskich BIZ, lecz coraz częściej firmy lokują swój kapitał poza jej obszarem. Działalność gospodarcza poza wspólnym rynkiem UE niesie określonego rodzaju ryzyko, np.: polityczne, rynkowe, walutowe i inne, które musi być brane pod uwagę przez racjonalnie działające przedsiębiorstwo zamierzające lokować swój kapitał w formie BIZ. Poziom ryzyka politycznego, czy rynkowego poza obszarem UE jest przeważnie wyższy. Staranny wybór destynacji BIZ jest bardzo istotny, bo pozwala przynajmniej częściowo ograniczyć niektóre rodzaje ryzyka towarzyszące międzynarodowej działalności gospodarczej firmy.

W przedmiotowym badaniu najważniejsze przy wyborze destynacji BIZ na terenie pozaunijnych państw europejskich okazywały się czynniki prawne i kosztowe. Przeciętny poziom ważności uzyskały czynniki polityczne, co może dziwić, np. w kontekście obecnej sytuacji na wschodzie Europy. Natomiast w przypadku wyboru destynacji pozaeuropejskich najważniejsze okazały się czynniki polityczne i prawne. Priorytetowe traktowanie czynników prawnych może oznaczać, że niektóre firmy są zainteresowane inwestycjami BIZ w postaci przepływów finansowych (tzw. kapitał w tranzycie). Ułatwia to możliwości transferowania zysków polskich firm za granicę oraz sprzyja „optymalizacji podatkowej”. Istnie- 
jące przepisy prawne i podatkowe niektórych krajów goszczących BIZ stanowią również zachętę do rejestrowania w nich spółek córek, za pośrednictwem których BIZ przekierowywane są na rynki trzecie.

Pewnym punktem odniesienia dla przedsiębiorstw rozważających w przyszłości wprowadzenie inwestycji bezpośrednich poza granicami Polski mogą być niniejsze badania, na podstawie których można ocenić, czym kierują się zarządy firm planujące wprowadzenie inwestycji bezpośrednich i poszukujące dla nich odpowiedniej destynacji.

Obecnie obserwujemy dynamicznie zmieniającą się sytuację geopolityczną i rynkową zarówno w Europie, jak i na świecie. Może to powodować pewne zmiany zarówno w zakresie preferowanych destynacji BIZ, jak i w ocenie determinantów wyboru tych destynacji. $\mathrm{Z}$ tego też względu podobne badanie w przyszłości powinno być powtarzane. Pozwoli to na bieżąco aktualizować kombinacje determinantów wyboru destynacji BIZ, jak i weryfikować ich poziom ważności.

Dodatkowo rozszerzając rodzaj zmiennych diagnostycznych oraz liczbę alternatywnych kierunków destynacji BIZ, możliwe będzie wskazanie potencjalnych problemów i zagrożeń związanych rozwijaniem tej formy inwestowania w określonych krajach.

\section{Literatura}

Breiman L., Friedman J.H., Olshen R.A., Stone C.J. [1984], Classification and Regression Trees, CRC Press, London.

Dunning J.H. [1981a], Explaining the International Direct Investment Position of Countries: Towards a Dynamic or Developmental Approach, „Weltwirtschaftliches Archiv", vol. 117, nr 1, http://dx.doi.org/10.1007/bf02696577.

Dunning J.H. [1981b], International Production and the Multinational Enterprise, George Allen \& Unwin, London.

Dunning J.H. [1988], The Eclectic Paradigm of International Production: A Restatement and Some Possible Extensions, ,Journal of International Business Studies”, vol. 19, nr 13, http://dx.doi.org/10.1057/palgrave.jibs.8490372.

Dunning J.H. [2004], Determinants of Foreign Direct Investment: Globalization-induced Changes and the Role of Policies [w:] Toward Pro-poor Policies. Aid, Institutions, and Globalization, red. B. Tungodden, N. Stern, I. Kolstad, World Bank, Washington.

Fry M. [1993], Foreign Direct Investment in a Macroeconomic Framework: Finance, Efficiency, Incentives, and Distortions, Working Paper WPS, nr 1141, World Bank, Washington.

Gatnar E. [2001], Nieparametryczna metoda dyskryminacji i regresji, Wydawnictwo Naukowe PWN, Warszawa.

Gatnar E. [2009], Drzewa klasyfikacyjne i regresyjne [w:] Statystyczna analiza danych $z$ wykorzystaniem programu $R$, red. M. Walesiak, E. Gatnar, Wydawnictwo Naukowe PWN, Warszawa. 
Jun K.W., Singh H. [1996], The Determinants of Foreign Direct Investment in Developing Countries, ,Transnational Corporations”, vol. 5, nr 2.

Kojima K. [1978], Direct Foreign Investment. A Japanese Model of Multinational Business Operations, Croom Helm, London.

Lukas R.E.B. [1993], On the Determinants of Direct Foreign Investment: Evidence from East and Southeast Asia, ,World Development”, nr 21, nr 3, http://dx.doi.org/ 10.1016/0305-750x(93)90152-y.

Mottaleb K.A. [2007], Determinants of Foreign Direct Investment and Its Impact on Economic Growth in Developing Countries, MPRA Paper nr 9457, https://mpra.ub.unimuenchen.de/9457/1/ (dostęp: 20.09.2015).

Ozawa T. [1992], Foreign Direct Investment and Economic Development, ,Transnational Corporation", vol. 1, nr 1.

Pilarska C. [2005], Bezpośrednie inwestycje zagraniczne w teorii ekonomii, Wydawnictwo Akademii Ekonomicznej w Krakowie, Kraków.

Przybylska K. [2001], Determinanty zagranicznych inwestycji bezpośrednich w teorii ekonomicznej. Empiryczna weryfikacja czynników lokalizacji zagranicznych inwestycji bezpośrednich w Czechach, Polsce i na Wegrzech, Zeszyty Naukowe Akademii Ekonomicznej w Krakowie, Seria Specjalna: Monografie, nr 144, Kraków.

Rymarczyk J. [2004], Internacjonalizacja i globalizacja przedsiębiorstwa, PWE, Warszawa.

\section{Identifying the Determinants in the Choice of Destination for Polish FDI outside the EU}

(Abstract)

The purpose of this article is to identify the main factors determining the choice of Polish foreign direct investment (FDI) destination outside the EU. The research includes the cost, market, efficiency, legal, social and political factors which may be important in the search for the beneficiaries of FDI. Data from a survey conducted among companies investing in FDI or planning this form of investment were used in the analysis. To classify the companies, decision trees were used, and created in accordance with a CART algorithm. These research methods enable the creation of company profiles with similar investment policies in terms how they prioritize their choice of investment destination. The study showed that when choosing a destination for FDI in European countries that are not EU members, the legal and cost factors were the most important, while political factors were also important in non-European destinations. The prominence of the legal factors may mean that some Polish companies are interested in FDI in the form of financial flows (ie. capital in transit) and tax optimisation.

Keywords: FDI, survey, classification trees, CART algorithm. 